ISOLATION OF CYTISINE FROM Thermopsis dolichocarpa

B. Babaev, T. T. Shaki rov,

V. G. Sidyakin, and S. A. Khamidkhodzhaev

UDC $547.944 / 945$

In order to broaden the raw-materials basis for the production of cytisine, we have studied the epigeal part of the plant Th. dolichocarpa [1], a perennial plant growing in Central Asia. Thickets are found mainly in the Gissar range along the rivers Guliob, Shargun', Karatag, and Khanaka, and also on the Darvaza and Vakhsh ranges of Tadzhikistan. The total area of growth is about 2000 ha, from which about 500 tons of the plant (in the dry state) can be collected each year.

We have performed a quantitative determination of the amount of cytisine in the various organs of Th. dolichocarpa collected in the gorge of the R. Shargun' in 1972:

\begin{tabular}{|c|c|c|c|}
\hline $\begin{array}{l}\text { Parts of the plant and } \\
\text { vegetation period }\end{array}$ & $\begin{array}{l}\text { Time of } \\
\text { collection }\end{array}$ & $\begin{array}{l}\text { Total alkaloids as } \% \text { of the } \\
\text { weight of the raw material }\end{array}$ & $\begin{array}{l}\text { Cytisine as \% of } \\
\text { of the raw mater }\end{array}$ \\
\hline $\begin{array}{l}\text { Epigeal part, budding } \\
\text { stage }\end{array}$ & $\mathrm{III} / 20-30$ & 2.1 & 0.5 \\
\hline Ripe seeds & VIII $/ 20$ & 3.5 & 1.62 \\
\hline Roots & $\mathrm{TV} / 15-30$ & 0.26 & 0.15 \\
\hline
\end{tabular}

Although the seeds contain more cytisine [2,3] than the epigeal part [4], the isolation of cytisine from the seeds is complicated by the large amounts of fatty and protein substances that they contain. Furthermore, the collection of the seeds on the industrial scale is far more difficult. Consequently, we investigated the epigeal part of $\mathrm{Th}$. dolichocarpa. The processes of extraction, sorption, and desorption of cytisine were studied. For its extraction from the plant raw material, the best results were obtained by using a $0.25 \%$ solution of sulfuric acid as solvent. The optimum results in the isolation of the cytisine from the extracts were given by the use of $\mathrm{KU}-2$ ion-exchange resin. In choosing the eluent for the desorption of the cytisine from the $\mathrm{KU}-2$ resin, various solvents and mixtures were tested. The best proved to be $90 \%$ ethanol containing $3 \%$ ammonia.

On the basis of the investigations performed, we have developed an adsorption method for obtaining cytisine from the epigeal part of Th. dolichocarpa, and the method is proposed for the production of cytisine. By this method, Th. dolichocarpa yields $2.1 \%$ of total alkaloids and $0.37 \%$ of cytisine on the air-dry raw material.

\title{
LITERATURF CITED
}

1. Flora of the USSR [in Russian], Moscow-Leningrad, Vol. XI (1945).

2. T. T. Shakirov, K. A. Sabirov, and R. I. Shamsutdinov, Khim. Prirodn. Soedin., 61 (1968).

3. T. T. Shakirov, R. I. Shamsutdinov, K. A. Sabirov, and E. E. Korotkova, USSR Authors' Certificate No. 204,497, Byul. Izobret., No. 22, 68 (1967).

4. M. Narmatov, Kh. A. Abduazimov, and S. Yu. Yunusov, Dokl. Akad. Nauk UzSSR, No. 3, 45 (1962).

Institute of the Chemistry of Plant Substances, Academy of Sciences of the Uzbek SSR. Translated from Khimiya Pri rodnykh Soedinenii, No. 3, pp. 444-445, May-June, 1973. Original article submitted December 30, 1972.

() 1975 Plenum Publishing Corporation, 227 West 17th Street, New York, N.Y. 10011. No part of this publication may be reproduced, stored in a retrieval system, or transmitted, in any form or by any means, electronic, mechanical, photocopying, microfilming, recording or otherwise, without written permission of the publisher. A copy of this article is available from the publisher for $\$ 15.00$. 